BUERKLE, UDO, and W. DAN MANSELL 1963. First nesting record of the Cattle Egret (Bubulcus ibis) in Canada. Auk 80(3): 378-379.

GODFREY, W. EARL. 1954. The Cattle Egret at sea off Newfoundland. Canadian Field-Naturalist 68(3): 139140.
${ }^{3}$ HJERTAAS, DALE. 1979. The Cattle Egret arrives in Saskatchewan. Blue Jay 37(2): 104-107.

${ }^{4}$ HOUSTON, C. S., and M.I. HOUSTON. 1974. The nesting season: June 1, 1974 -July 31, 1974, Northern Great Plains. American Birds 28(5): 915-918.

\title{
THE GREAT GRAY OWLS THAT WEREN'T
}

C. STUART HOUSTON, 863 University Drive, Saskatoon, Saskatchewan, S7N 0J8, CHRISTOPHER J. ESCOTT, 271 Sylvian Way, Saskatoon, Saskatchewan, S7H 5 G1 and ROBERT C. GODWIN, 313 McMaster Crescent, Saskatoon, Saskatchewan. S7H 4E5

On 22 July 1982 at 2200 Houston received a phone call from Doug Sadler reporting three or four hornless, earless, large owls sitting on poles near his farm home $10 \mathrm{mi}$. south of Saskatoon. Sadler had earlier seen one of these owls in daylight and noted the yellow eyes that excluded the possibility of Barred Owls, for which there is only one nest record in Saskatchewan. Instead, Sadler felt these must be juvenile Great Gray Owls, for which there are only two, possibly three, documented nest records for the province. Since even at this latitude it was already pitch dark, we arranged to meet at Sadler's farm the following evening at 2000. By that time Marc Bechard would have arrived from Huntington, West Virginia, for a weekend of Swainson's Hawk banding.

On 23 July, joined by Bechard, Mary Houston, Kelly Wylie, and Chris Escott, Sadler and the five of us searched the small aspen "bluffs" where the owls had been seen the previous evening. After two hours without success, just before 2200, we heard the plaintive calls of the hungry young owls. Their call was, to our ears, exactly the same as the call of the young Great Gray Owl on Roger Tory Peterson's Field Guide to the Western Birds song album to which we had listened at supper time. We followed the calls for a quarter mile and obtained good silhouettes against the night sky of very large owls with smooth hornless heads. We weren't sure the heads were large enough for Great Gray

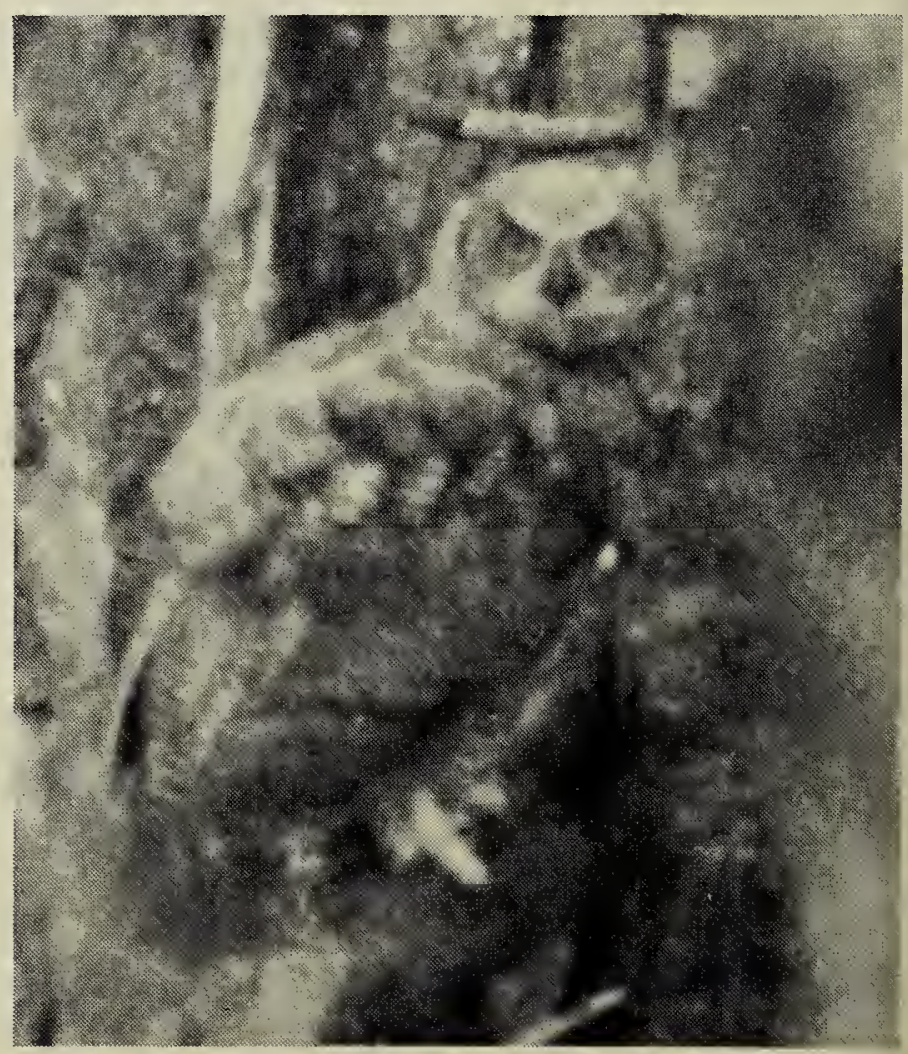

Young Great Horned Owl.

Chris Escott 
Owls. The head and neck seemed arched or stooped after the manner of some paintings of Barred Owls. The owls were "spooky" and wouldn't allow a near approach, quite different from the normally absurdly tame Great Grays. We chased the owls from bluff to bluff, all the time following the presumed hunger calls of the three young.

After 90 minutes of this it was pitch dark, and the owls were calling from a larger bluff across from Sadler's, so we tried putting out a Bal-chatri trap containing two mice, hoping to lure them in for capture and definite identification. We had no luck and returned home by midnight.

Back home, we again listened to the Peterson record, confirming the similarity of the calls with that of the Great Gray. Although it was now 0100 in Winnipeg, Houston phoned Bob Nero and routed him out of bed to ply him with questions. Having visited over 1500 nests of Great Horned Owls, having caught Horned Owl nestlings that had been out of the nest for two weeks or more on a number of occasions, by which time rudimentary "ears" were begining to appear, Houston had never heard this call from a Great Horned Owl. Nero assured Houston that Barred Owl young do not make such a noise. Nero felt that the aspen parkland habitat described to him was not unlike that around East Bay, Manitoba where Ed Robinson once had a nesting Great Gray Owl.

Nero assured Houston that, yes, Great Grays could land on fence posts, yes, they did not always allow a close approach, and yes, the three calling birds must be young that were raised nearby. Nero suggested that every hawk and crow nest within a half-mile or mile of the sighting be climbed in a search for confirmatory Great Gray Owl feathers.

The next day Houston, Bechard and Wylie went off to band the Swainson's hawks located by Jean Harris near Kindersley, while Escott returned with Jim Wedgwood to the scene of the crime. The lack of horns or ears and the yellow eyes were evident at close range in good light, and seemed to confirm the diagnosis of Great Gray Owl.

Responding to the Rare Bird Alert call, Stanley Shadick, Bob Godwin and Nigel Caulkett next appeared. Godwin was skeptical, for he had heard Great Horned Owls give the same peculiar short scream on five previous occasions at dusk, only in August and September, and only in the Great Sandhills near Tompkins and Cabri and along the Saskatchewan River near Fort a la Corne. One of the young owls was located, and watched while it gave the call. It was too light in colour for a Great Gray, and had tiny ear tufts barely visible. Godwin recorded the calls on tape for over 10 minutes, with one call about every 30 seconds.

Escott returned for a third time, on 27 July, and studied all three young. One was light in colour and two were dark. They had a wide $V$ pattern on the forehead, the facial disk had two, not four, circular parallel lines, and the beak was dark and relatively small - all distinguishing features of young Great Horned Owls not shared by young Great Gray Owls. Escott obtained the photograph shown here.

Young Great Horned Owls are fed by their parents for about three months after they leave the nest, and during this time band recoveries show they usually stay within a few miles of the nest. But how many readers have heard this repetitive call of the Great Horned Owl, so like the hunger call of the young Great Gray? What times has it been heard and in what circumstances? Perhaps knowledge of this little known, persistent call of our commonest owl will help others to avoid making the same humiliating mistake that a number of us made. 